\title{
Acute and Sub-acute Toxicity Profile of Aqueous Leaf Extract of Nymphaea lotus Linn (Nymphaeaceae) in Wistar Rats
}

\author{
Olubunmi J Sharaibi ${ }^{1}$, Oluwatoyin T Ogundipe $^{2}$, Olubunmi A Magbagbeola ${ }^{3}$, \\ Mutiu I Kazeem ${ }^{1}$ and Anthony J Afolayan ${ }^{1 *}$ \\ ${ }^{1}$ Medicinal Plants and Economic Development (MPED) Research Center, University of Fort Hare, Alice 5700, South Africa, \\ ${ }^{2}$ Department of Botany, Akoka Campus, ${ }^{3}$ Department of Biochemistry, Idi Araba Campus, University of Lagos, Lagos, Nigeria \\ *For correspondence: Email: aafolayan@ufh.ac.za; Tel: +27822022167
}

\begin{abstract}
Purpose: To evaluate the acute and sub-acute toxicity profile of the aqueous leaf extract of Nymphaea lotus $L$ in Wistar rats.

Methods: Acute toxicity study was performed by administering a single oral dose of $5000 \mathrm{mg} / \mathrm{kg}$ body weight of the extract to 5 rats while distilled water was given to another 5 rats (control), and the animals were observed for 14 days. Thereafter, 50, 100 and $200 \mathrm{mg} / \mathrm{kg}$ doses of the extract were administered to different groups of 5 rats each daily for 28 days while control received distilled water. At the end of the experiment, the animals were sacrificed and the serum obtained was used for the assessment of haematological and biochemical parameters. Histological examination was also performed on the liver and kidney of the rats.

Results: The concentrations of alanine aminotransferase (42.56 U/L), aspartate aminotransferase (126.01 U/L) and alkaline phosphatase (183.33 U/L) significantly decreased while creatinine $(0.64$ $\mathrm{mg} / \mathrm{dL}$ ) and chloride ions $(94.50 \mathrm{mmo} / \mathrm{L})$ were significantly elevated $(p<0.05)$ compared to those of control following the extract treatment. Haematological parameters were not significantly different ( $p>$ 0.05 ) from those of control except white blood cell count $\left(7.80 \times 10^{9} / \mathrm{L}\right)$, lymphocytes $(5.20 \%)$ and monocytes $(2.72 \%)$ which were significantly elevated $(p<0.05)$ in the 100 and $200 \mathrm{mg} / \mathrm{kg}$ treated groups. Histopathology did not reveal any sign of lesions or pathological changes in the organs that could be attributed to treatment with the plant extract.

Conclusions: These results suggest that the aqueous leaf extract of Nymphaea lotus may be safe for use at the doses tested.
\end{abstract}

Keywords: Nymphaea lotus, Toxicity, White blood count, Alkaline phosphatase, Histology

Tropical Journal of Pharmaceutical Research is indexed by Science Citation Index (SciSearch), Scopus, International Pharmaceutical Abstract, Chemical Abstracts, Embase, Index Copernicus, EBSCO, African Index Medicus, JournalSeek, Journal Citation Reports/Science Edition, Directory of Open Access Journals (DOAJ), African Journal Online, Bioline International, Open-J-Gate and Pharmacy Abstracts

\section{INTRODUCTION}

Nymphaea lotus L, commonly known as white water lily by Egyptians, belongs to the family Nymphaeaceae. It is a perennial plant growing in clear, warm, still and slightly acidic waters to a height of $45 \mathrm{~cm}$ [1]. The lily pads float on water while the blossoms rise above the water. The flowers are white, and sometimes with a pink tinge. The leaves vary from green to reddishbrown, with a number of purple spots. The plant is native to the Nile [1] and is grown in various parts of East Africa and Southeast Asia [2].

This plant has extensive uses in traditional medicine [3]. Its leaf is used as an aphrodisiac, 
astringent, cardiotonic, sedative and antiinflammatory agent [4]. It produces calming and sedative effects on the nervous system, and is useful in the treatment of insomnia, anxiety and related disorders $[5,6]$. The flowers are also used for preparing tea used in the treatment of diabetes while its rhizomes are used to treat diarrhoea, dysentery, dyspepsia and general weakness [2].

The leaves are also used in the treatment of indigestion, heart diseases, stomach aches, cancer and as anti-hemorrhagic [7]. Many biological activities, including anticancer and antiviral, has been attributed to gallic and ellagic acid which are widely present in $N$. lotus [8]. Our previous study also showed that the aqueous extract of $N$. lotus is rich in phytochemicals such as proanthocyanidins, phenolics, tannins, flavonoids and saponins [9].

Despite long record of medicinal usage of $N$. lotus, there is dearth of information on its potential safety and or toxicity. Therefore, the purpose of the present study was to provide information on the safety/toxicity of the aqueous extract of Nymphaea lotus in Wistar rats.

\section{EXPERIMENTAL}

\section{Plant material}

Fresh leaves of Nymphaea lotus were collected from Badagry Area of Lagos, Southwest Nigeria in June, 2012 and were authenticated by $\mathrm{Mr}$ Sanni of the Lagos State University herbarium. Voucher specimen (LSH. 2012/6) was prepared and deposited in the herbarium for future reference. The leaves were carefully rinsed under running water, air dried to constant weight in the laboratory and later pulverized before extraction.

\section{Chemicals}

The assay kits for the determination of alanine aminotransferase (ALT) and aspartate aminotransferase (AST) were supplied by Randox Laboratories Ltd, United Kingdom while that of alkaline phosphatase (ALP) and gamma glutamyl transferase (GGT) were obtained from Roche Diagnostic $\mathrm{GmbH}$, Mannhein, Germany. All other reagents were of analytical grade and prepared in glass-distilled water.

\section{Extract preparation}

About $100 \mathrm{~g}$ of the powdered plant material was extracted in $1000 \mathrm{ml}$ of distilled water for $24 \mathrm{~h}$ at
$30{ }^{\circ} \mathrm{C}$ on an orbital shaker (Stuart Scientific Orbital Shaker, UK). The extract was filtered using a Buchner funnel and Whatman no.1 filter paper. The filtrate was freeze dried using Savant Refrigerated Vapor Trap (RTV 4104, USA).

\section{Experimental animals}

Male Wistar rats weighing 220 - $250 \mathrm{~g}$ were obtained from the animal house of the School of Biological and Environmental Sciences, University of Fort Hare, Alice 5700, South Africa. They were housed in clean plastic cages under standard environmental conditions of temperature $\left(23 \pm 1{ }^{\circ} \mathrm{C}\right)$ and relative humidity (45 - $50 \%$ ) under a $12 \mathrm{~h}$ dark-light cycle. They were acclimatized to animal house conditions for 7 days before dosing and allowed free access to drinking water and standard pellets (Pioneer Food (Pty) Ltd, Huguenot, South Africa). All experimental protocols were approved by the Animal Ethics Committee of the University of Fort Hare, Alice 5700, South Africa (UFH 13/01) and according to the Guide for the Care and Use of Laboratory Animals [10].

\section{Acute toxicity test}

This was performed according to the Organization of Economic Co-operation and Development guideline for testing chemicals [11]. Ten rats were randomly assigned into two groups of five rats each. Group A was administered with a single oral dose of $1 \mathrm{ml}$ of $5000 \mathrm{mg} / \mathrm{kg}$ body weight of the plant extract while group $B$ (the control) received $1 \mathrm{ml}$ of distilled water. Body weights of the rats were measured at the commencement (day 1), day 7 and at the end of the experiment. Signs of toxicity and mortality were observed after the administration at the first, second, fourth and sixth hour and once daily for 14 days.

\section{Sub-acute toxicity test}

Twenty rats of Wistar strain were randomly divided into four groups of five animals each. Group 1 (control) was orally administered $1 \mathrm{ml}$ distilled water, groups 2 to 4 were administered 1 $\mathrm{ml}$ of 50,100 and $200 \mathrm{mg} / \mathrm{kg}$ body weight of the plant extract for 28 days [12]. The extract and distilled water were administered daily using orogastric tubes. The initial body weights of the rats were recorded on day one and were subsequently taken daily throughout the duration of the experiment. On the 29th day, rats were humanely sacrificed under halothane anaesthesia for haematological, biochemical and histopathological analysis [13]. 


\section{Preparation of the serum}

Briefly under halothane anaethesia, the neck area of the rats was quickly shaved to expose the jugular veins. The veins after being slightly displaced (to avoid contamination with interstitial fluid) were cut with sterile surgical blade and an aliquot of the blood was collected into BD vacutainer sample bottles for the haematological analysis [13]. The remainder was allowed to clot for $10 \mathrm{~min}$ at room temperature, and then centrifuged at $1282 \mathrm{~g} \times 5 \mathrm{~min}$ using Hermie Bench Top Centrifuge (Model Hermie Z300, Hamburg, Germany). Sera were used within $12 \mathrm{~h}$ of preparation for various biochemical assays. Livers and kidneys were carefully excised, freed of fat, blotted with clean tissue paper and then weighed for the determination of organ-body weight ratio.

\section{Determination of hematological parameters}

Determination of haematological parameters such as red blood count (RBC), haemoglobin (HGB), packed cell volume (PCV), mean corpuscular volume (MCV), mean corpuscular haemoglobin $(\mathrm{MCH})$, mean corpuscular haemoglobin concentration (MCHC), platelet (PLT), white blood cells (WBC) and white blood cell count were carried out using Beckman Coulter (Beckman Coulter Inc., CA, USA.) [14]

\section{Determination of biochemical parameters}

The activities of aspartate aminotransferase (AST), alanine aminotransferase (ALT), alkaline phosphate (ALP) and gamma glutaryltransferase (GGT), total bilirubin, total protein and albumin were determined using Piccolo express automatic chemistry analyzer (Abaxis Inc. Union City, CA 94587, USA). The serum levels of creatinine, magnesium, calcium, chloride, urea, sodium and potassium ions were also determined by the method of Tietz [15].

\section{Histopathological examination}

The organs (livers and kidneys) were fixed in 10 $\% \quad(v / v)$ formaldehyde, dehydrated through ascending grades of ethanol $(70 \%, 90 \%$ and 95 $\% \mathrm{v} / \mathrm{v})$, cleaned in xylene and embedded in paraffin wax. Tissue sections were prepared and stained with hematoxylin/eosin [16]. The photomicrographs were taken at $\times 400$ using the Leitz, DIALUX research microscope.

\section{Statistical analysis}

Statistical analysis was performed using GraphPad Prism 5 statistical package (GraphPad
Software, San Diego MA, USA). Data were expressed as means of five replicates \pm SEM. They were subjected to one- way ANOVA followed by Bonferroni post hoc test. Values were considered statistically significant at $p<$ 0.05 .

\section{RESULTS}

\section{Acute toxicity}

The oral administration of the aqueous extract of fresh leaves of Nymphaea lotus did not cause mortality of any rat during the 14 day observation. There was also no sign of toxicity, behavioural or physiological changes. There was no significant change between the body weights of the control and extract treated rats throughout the study (Table 1).

Table 1: Effect of single oral administration of Nymphaea lotus aqueous leaf extract $(5000 \mathrm{mg} / \mathrm{kg})$ on the body weights of rats

\begin{tabular}{lccc}
\hline Groups & Day 1 & Day 7 & Day 14 \\
\hline Control & $239.10 \pm$ & $244.75 \pm$ & $248.58 \pm$ \\
(distilled water) & 3.90 & 5.52 & 7.11 \\
Extract (5000 & $242.42 \pm$ & $245.66 \pm$ & $251.72 \pm$ \\
$\mathrm{mg} / \mathrm{kg})$ & 4.22 & 6.24 & 7.74 \\
\hline
\end{tabular}

Values are means \pm SEM $(n=5)$. *Values are significantly different from the control $(p<0.05)$

\section{Effect on haematological parameters}

Table 2 showed the effect of the aqueous extract of Nymphaea lotus leaves on the haematological parameters of rats. White blood cell count (WBC) was significantly higher in all the treated groups compared to the control while only $100 \mathrm{mg} / \mathrm{kg}$ and $200 \mathrm{mg} / \mathrm{kg}$ group had significant differences $(p<0.05)$ in their monocyte, lymphocyte and eosinophil levels compared to the control. There were also significant differences in the RCW and platelets of $50 \mathrm{mg} / \mathrm{kg}$ group compared to the other groups. There were no significant differences $(p>0.05)$ in red blood cell (RBC), haemoglobin (HGB), PCV, MCH, MCHC, neutrophil and basophil concentrations when compared with the control.

\section{Effect on the biochemical parameters of rats}

Table 3 showed the effects of the aqueous extract of Nymphaea lotus on the biochemical parameters of rats. The activity of alkaline phosphatase was significantly reduced $(p<0.05)$ in all the treated groups compared to the control. 
Table 2: Effect of aqueous extract of Nymphaea lotus on haematological parameters of rats

\begin{tabular}{|c|c|c|c|c|}
\hline Parameter & Control & $50 \mathrm{mg} / \mathrm{kg}$ & 100 mg/kg & $200 \mathrm{mg} / \mathrm{kg}$ \\
\hline WBC $\left(\times 10^{9} / L\right)$ & $5.82 \pm 2.49$ & $7.61 \pm 1.06^{*}$ & $7.09 \pm 0.39^{*}$ & $7.80 \pm 0.50^{*}$ \\
\hline $\operatorname{RBC}\left(\times 10^{12} / L\right)$ & $8.05 \pm 0.26$ & $8.26 \pm 0.31$ & $8.43 \pm 0.41$ & $8.37 \pm 0.82$ \\
\hline $\mathrm{Hb}(\mathrm{g} / \mathrm{dL})$ & $15.12 \pm 0.61$ & $15.60 \pm 0.01$ & $15.30 \pm 0.71$ & $15.40 \pm 0.98$ \\
\hline PCV $(\%)$ & $0.51 \pm 0.03$ & $0.52 \pm 0.01$ & $0.50 \pm 0.05$ & $0.51 \pm 0.05$ \\
\hline $\operatorname{MCV}(\mathrm{fl})$ & $61.63 \pm 2.83$ & $62.60 \pm 0.85$ & $59.80 \pm 2.69$ & $61.03 \pm 2.61$ \\
\hline $\mathrm{MCH}(\mathrm{pg})$ & $18.91 \pm 0.17$ & $18.88 \pm 0.71$ & $18.71 \pm 0.01$ & $18.43 \pm 0.64$ \\
\hline $\mathrm{MCHC}(\mathrm{g} / \mathrm{dL})$ & $30.67 \pm 1.27$ & $30.10 \pm 0.71$ & $30.85 \pm 1.48$ & $30.23 \pm 1.18$ \\
\hline RCW (\%) & $12.87 \pm 0.81$ & $13.80 \pm 0.28^{*}$ & $12.80 \pm 0.14$ & $12.77 \pm 0.81$ \\
\hline Platelets $\left(\times 10^{y} / \mathrm{L}\right)$ & $878.67 \pm 12.3$ & $837.12 \pm 17.3^{*}$ & $878.33 \pm 13.4$ & $876.33 \pm 14.2$ \\
\hline Neutrophils (\%) & $0.89 \pm 0.22$ & $0.87 \pm 0.33$ & $0.85 \pm 0.01$ & $0.91 \pm 0.16$ \\
\hline Monocytes (\%) & $2.92 \pm 0.18$ & $2.81 \pm 0.04$ & $2.78 \pm 0.01^{*}$ & $2.72 \pm 0.16^{*}$ \\
\hline Lymphocytes (\%) & $4.41 \pm 0.37$ & $4.54 \pm 0.01$ & $5.20 \pm 0.01^{*}$ & $5.17 \pm 0.35^{*}$ \\
\hline LUC (\%) & $0.70 \pm 0.04$ & $0.60 \pm 0.01$ & $0.80 \pm 0.02$ & $0.70 \pm 0.10$ \\
\hline Eosinophils (\%) & $0.14 \pm 0.05$ & $0.15 \pm 0.01$ & $0.20 \pm 0.06^{\star}$ & $0.20 \pm 0.01^{*}$ \\
\hline Basophils (\%) & $0.09 \pm 0.04$ & $0.07 \pm 0.06$ & $0.08 \pm 0.01$ & $0.09 \pm 0.01$ \\
\hline
\end{tabular}

Values are Mean \pm SEM $(n=5)$. *Values are significantly different from the control $(p<0.05)$. WBC: white blood cell, RBC: red blood cell, Hb: haemoglobin, PCV: packed cell volume, MCV: mean corpuscular volume, $M C H$ : mean corpuscular haemoglobin, MCHC: mean corpuscular haemoglobin concentration, RCW: red cell width, LUC: large unstained cells

Administration of 100 and $200 \mathrm{mg} / \mathrm{kg}$ of the extract significantly decreased $(p<0.05)$ aspartate aminotransferase (AST) while only 100 $\mathrm{mg} / \mathrm{kg}$ of the extract produced significant reduction $(p<0.05)$ in the alanine aminotransferase activity compared to the control group. There were significant differences $(p<$ 0.05 ) in the magnesium and chloride ion concentrations of 100 and $200 \mathrm{mg} / \mathrm{kg}$ groups compared to the control while the creatinine concentration of all the treated groups were significantly higher $(p<0.05)$ than the control.

\section{Effect on body and organ weights of rats}

The effect of the administration of the aqueous extract of Nymphaea lotus on the body and organ weights of wistar rats is shown in Table 4. No significant difference $(p>0.05)$ was observed in the weights of the organs of animals treated with the aqueous extract of Nymphaea lotus leaves compared to the control group.

\section{Effect on liver and kidney histology of rats}

Figures 1 and 2 showed the effects of aqueous extract of Nymphaea lotus on the liver and kidney tissues of rats. No lesions or pathological changes of the organs attributable to the administration of the extract were observed in all the treated groups.

Table 3: Effect of aqueous extract of Nymphaea lotus leaves on biochemical parameters of rats

\begin{tabular}{lcccc}
\hline Parameter & Control & $\mathbf{5 0 ~} \mathbf{~ g / k g}$ & $\mathbf{1 0 0} \mathbf{~} \mathbf{g} / \mathbf{k g}$ & $\mathbf{2 0 0} \mathbf{~} \mathbf{g} / \mathbf{k g}$ \\
\hline Glucose $(\mathrm{mg} / \mathrm{dL})$ & $22.60 \pm 1.25$ & $21.33 \pm 1.37$ & $21.01 \pm 0.69$ & $21.04 \pm 1.41$ \\
Albumin (g/dL) & $2.31 \pm 0.15$ & $1.93 \pm 0.15$ & $2.01 \pm 0.14$ & $2.10 \pm 0.28$ \\
Total protein (g/dL) & $6.60 \pm 0.53$ & $7.01 \pm 0.17$ & $6.35 \pm 0.35$ & $7.11 \pm 0.14$ \\
Total bilirubin (mg/dL) & $0.46 \pm 0.11$ & $0.51 \pm 0.17$ & $0.56 \pm 0.21$ & $0.45 \pm 0.07$ \\
AST (U/L) & $183.33 \pm 1.64$ & $181.21 \pm 2.83$ & $172.33 \pm 9.42^{*}$ & $126.01 \pm 6.78^{*}$ \\
ALP (U/L) & $231.33 \pm 8.53$ & $183.33 \pm 4.76^{*}$ & $184.25 \pm 2.83^{*}$ & $183.51 \pm 1.76^{*}$ \\
ALT (U/L) & $47.61 \pm 1.93$ & $46.67 \pm 1.25$ & $42.56 \pm 0.56^{*}$ & $48.50 \pm 0.77$ \\
GGT (U/L) & $5.33 \pm 0.58$ & $5.67 \pm 0.58$ & $5.33 \pm 2.08$ & $5.21 \pm 1.41$ \\
Sodium (mmol/L) & $148.00 \pm 2.08$ & $148.33 \pm 0.58$ & $145.51 \pm 0.71$ & $143.5 \pm 0.17$ \\
Potassium (mmol/L) & $8.90 \pm 0.69$ & $8.31 \pm 0.35$ & $8.52 \pm 0.01$ & $8.55 \pm 0.12$ \\
Chloride (mmol/L) & $91.07 \pm 3.78$ & $91.33 \pm 1.15$ & $92.5 \pm 2.12$ & $94.5 \pm 2.12^{*}$ \\
Creatinine (mg/dL) & $0.23 \pm 0.06$ & $0.61 \pm 0.11^{*}$ & $0.62 \pm 0.02^{*}$ & $0.64 \pm 0.14^{*}$ \\
Calcium (mg/dL) & $10.30 \pm 0.43$ & $10.32 \pm 0.21$ & $10.30 \pm 0.14$ & $9.85 \pm 0.35$ \\
Magnesium (mg/dL) & $3.37 \pm 0.40$ & $3.69 \pm 0.14$ & $4.13 \pm 0.40^{*}$ & $4.05 \pm 0.07^{*}$ \\
\hline
\end{tabular}

Values are Mean \pm SEM $(n=5)$. "Values are significantly different from the control $(p<0.05)$. AST: aspartate aminotransferase, ALP: alkaline phosphatase, ALT: alanine aminotransferase, GGT: gamma glutamyl transferase 
Table 4: Effect of Nymphaea lotus aqueous leaf extract on the body and organ weights of rats

\begin{tabular}{lcccc}
\hline Weight $\mathbf{( g )}$ & Control & $\mathbf{5 0} \mathbf{~} \mathbf{g} / \mathbf{k g}$ & $\mathbf{1 0 0} \mathbf{~} \mathbf{g} / \mathbf{k g}$ & $\mathbf{2 0 0} \mathbf{~} \mathbf{g} / \mathbf{k g}$ \\
\hline Initial body weight & $246.14 \pm 2.48$ & $247.31 \pm 2.97$ & $249.54 \pm 1.47$ & $250.14 \pm 2.97$ \\
Final body weight & $261.27 \pm 2.85$ & $259.31 \pm 2.28$ & $262.53 \pm 3.01$ & $263.31 \pm 2.92$ \\
Liver & $9.80 \pm 0.12$ & $9.76 \pm 1.10$ & $9.73 \pm 0.46$ & $9.86 \pm 0.42$ \\
Kidney & $2.43 \pm 0.12$ & $2.39 \pm 0.25$ & $2.41 \pm 0.21$ & $2.42 \pm 0.42$ \\
Heart & $1.47 \pm 0.13$ & $1.46 \pm 0.12$ & $1.44 \pm 0.71$ & $1.45 \pm 0.21$ \\
\hline
\end{tabular}

Values are means \pm SEM $(n=5)$. ${ }^{*}$ Values are significantly different from the control $(p<0.05)$
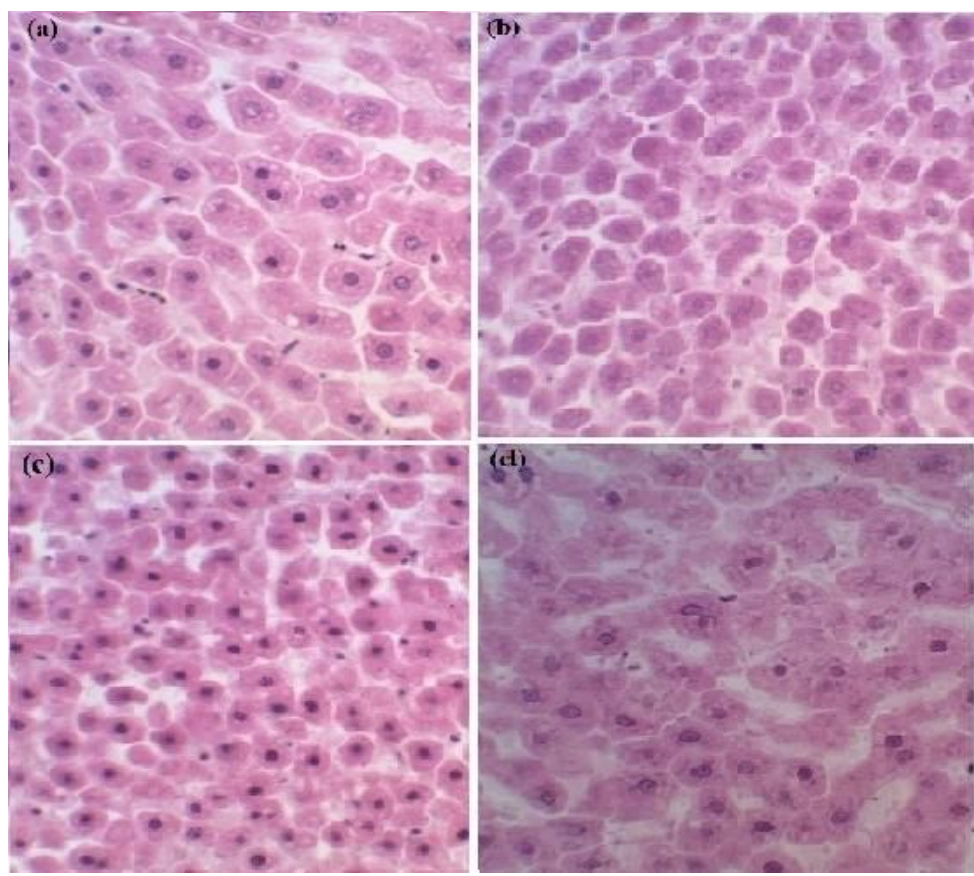

Figure 1: Photomicrographs of liver of wistar rats treated with (a) $1 \mathrm{ml}$ distilled water as normal control (b) 50 $\mathrm{mg} / \mathrm{kg}$ extract of $\mathrm{N}$. lotus (c) $100 \mathrm{mg} / \mathrm{kg}$ extract of $N$. lotus (d) $200 \mathrm{mg} / \mathrm{kg}$ extract of $\mathrm{N}$. lotus for 28 days. Haematoxylin-eosin, $\times 400$
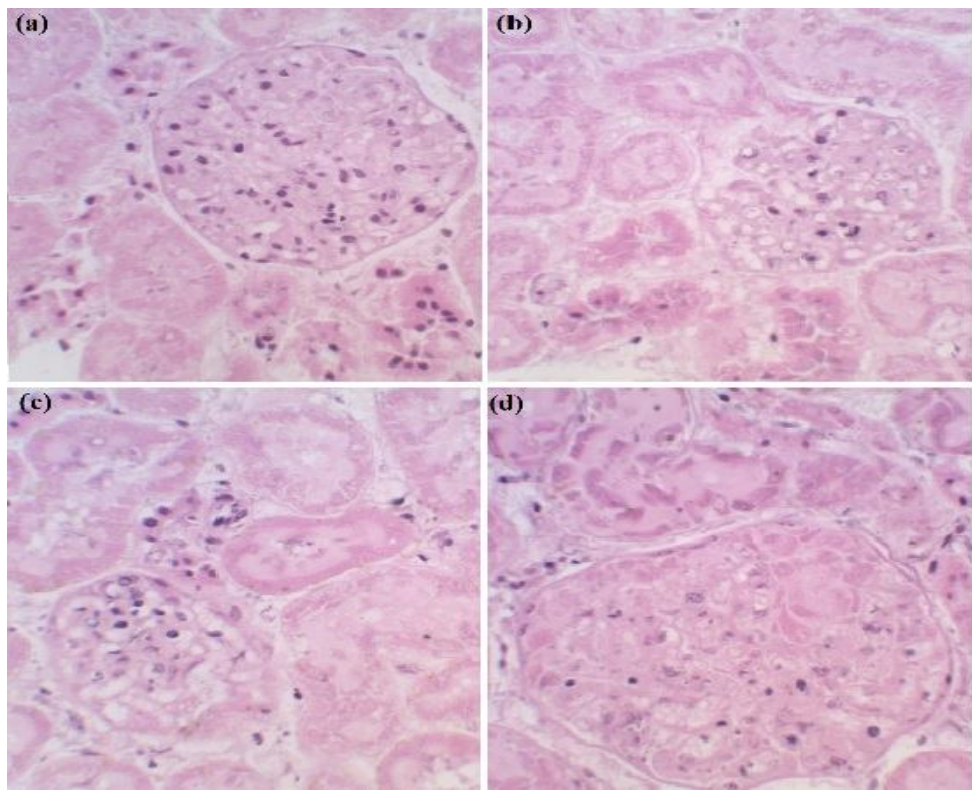

Figure 2: Photomicrographs of kidney of wistar rats treated with (a) $1 \mathrm{ml}$ distilled water as normal control (b) 50 $\mathrm{mg} / \mathrm{kg}$ extract of $N$. lotus (c) $100 \mathrm{mg} / \mathrm{kg}$ extract of $N$. lotus (d) $200 \mathrm{mg} / \mathrm{kg}$ extract of $N$. lotus for 28 days. Haematoxylin-eosin, $\times 400$ 


\section{DISCUSSION}

The observation that a single oral administration of $5000 \mathrm{mg} / \mathrm{kg}$ body weight aqueous extract of Nymphaea lotus leaves did not cause any mortality or alteration in behavioural or physiological state of rats in this study is an indication that the plant extract is not harmful at the tested dose and that its $L D_{50}$ is likely to be greater than $5000 \mathrm{mg} / \mathrm{kg}$.

The haemopoietic system serves as important target for toxic chemicals and is a sensitive index of pathological conditions [17]. In the present study, treatment with Nymphaea lotus did not produce any alteration in haematological parameters except the white blood cell (WBC) parameters which were significantly increased when compared with the control.

However, the increase in WBC production is not deleterious to the body as WBC play vital roles in immune system. They fight infections and are responsible for the production of antibodies which help to fight foreign materials in the body [18]. This suggests that Nymphaea lotus may help boost the immune system. Since lymphocyte is the main effector cells of the immune system [13], its observed elevation in this study may indicate an improvement in the immunity of the rats while reduced monocyte level possibly suggests that the extract did not cause any infection.

Many enzymes found in the serum may not have originated from the extracellular fluid. Usually during tissue damage, some of these enzymes leaks into the serum due to alteration of the membrane permeability [19]. Serum enzyme measurements are therefore a valuable tool in clinical diagnosis, providing information on the effect and nature of pathological damage to any tissue. ALP and GGT are ectoenzymes of the plasma membrane whereas ALT and AST are of the cytosol [20].

Decrease in the activities of serum ALP, ALT and AST may suggest inhibition of enzyme activity by the chemical compound (s) in the extract or inactivation of their activities in situ [21]. Alterations in the activities of these hepatic enzymes may imply damage to the structural integrity of the liver. Since serum proteins such as albumin and globulin could be used to assess the functional capacity of the liver, their nonsignificant effect in this study may imply that the secretory capacity of the liver is in good state.

Previous studies have shown that electrolytes play central role in gaseous exchange and inter- compartmental water balance [22]. Elevated or low serum electrolyte levels may have resulted in hypo or hyper functioning of related organs or tissues [23]. Clinical electrolytes such as sodium, potassium, chloride and bicarbonate ions are part of the parameters used in the assessment of kidney function. The elevation or depletion of any one of them is an indication of kidney dysfunction [24]. Increased serum creatinine observed with the administration of the extract in this study could be an indication of glomerular dysfunction [25]. The observed increase in the chloride ion concentration may be desirable due to the fact that excess chloride can react with hydrogen ion in the gastric mucosal gland to form $\mathrm{HCl}$ which may destroy pathogenic micro-organisms in the intestinal lumen [26].

Assessment of the effect of the plant extract on body weight and organs of experimental animals is an important test in toxicity evaluation [27]. The alteration in overall body weight or relative organ weight ratio may be an indication of impairment in the normal functioning of the organs [28]. Generally, reduction in body weight and relative organ weights is a simple and sensitive index of toxicity after exposure to potentially toxic substances [29].

The administration of the extract did not cause any marked differences in body weight of the treated groups when compared with the control. Both the control and the treated groups showed a progressive increase in body weight and organs over the duration of the experiment. The increase in body weight could be attributed to the nutritive components in their feed and plant extract [14].

In toxicological studies, histopathological examination provides supportive evidence for biochemical and haematological observations [30]. In the present study, no abnormality (hyperthropy, hypothropy or necrosis) was observed with respect to gross or histopathological examinations of the organs. This may imply that the plant extract may not be toxic to the animals or that the alterations produced in some serum biochemical parameters were mild and or yet to manifest in organ damage.

\section{CONCLUSION}

Although there were some alterations in some biochemical and haematological parameters of animals administered varying doses of Nymphaea lotus, no alteration was observed in the liver and kidney tissues. Thus, this plant may be safe as an oral remedy for the treatment of 
indigestion, inflammation, diabetes and infertility at the doses tested.

\section{ACKNOWLEDGEMENT}

The authors wish to thank the University of Fort Hare, South Africa and National Research Foundation of South Africa for financial support.

\section{REFERENCES}

1. Siddhanta AK, Mody KH, Ramavat BK, Chauhan VD, Garg HS, Goel AK, Doss MJ, Srivastava MN, Patnaik GK, Kamboj VP. Bioactivity of marine organisms: Part VIII - Screening of some marine flora of western coast of India. Indian J Exp Biol 1997; 35: 638-643.

2. Wee YC. A guide to medicinal plants. Singapore: Singapore Science Centre 1992; $p 108$.

3. Mohammed HA, Awodoyin RA, Daddy F, Adesina GO. Ethnobotany of water lilly (Nymphaea lotus Linn) among the riparian communities in Nigeria: $A$ casestudy of Kanji Lake basin. Biolog Environ 2008; 5: 5255.

4. James $A D$. Duke's handbook of medicinal plants of the Bible. USA: Taylor and Francis Group 2008. pp 302305.

5. Elegami AA, Bates C, Gray Al, Mackay SP, Skellern GG, Waigh $R D$. Two very unusual macrocyclic flavonoids from the water lily Nymphaea lotus. Phytochem 2003; 63: 727-731.

6. Akinjogunla OJ, Adegoke AA, Udokang IP, AdebayoTayo BC. Antimicrobial potential of Nymphaea lotus (Nymphaeaceae) against wound pathogens. J Med Plants Res 2009; 3: 138-141.

7. Sowemimo $A A$, Omobuwajo OR, Adesanya SA. Constituents of Nymphaea lotus Linn. Nig J Nat Product Med 2007; 11: 1-2.

8. Thippeswamy BS, Brijesh M, Veerapur VP, Gourav G. Anxiolytic activity of Nymphea alba Linn. in mice as experimental models of anxiety. Indian J Pharmacol 2011; 43: 50-55.

9. Afolayan AJ, Sharaibi OJ, Kazeem MI. Phytochemical analysis and in vitro antioxidant activity of Nymphaea lotus L. Inter J Pharmacol 2013; 9: 297-304.

10. National Academy of Sciences. Guide for the care and use of laboratory animals, 8th ed, Washington: National Academic Press 2011; p 246.

11. Organization for Economic Cooperation and Development (OECD). OECD guidelines for testing of chemicals - Acute Oral Toxicity methods. No. 423, 2001; pp 1-13.

12. Organization for Economic Cooperation and Development (OECD). OECD guidelines for testing of chemicals - Repeated dose 28-day oral toxicity in rodents. No. 407, 2008; pp 1-14

13. Ashafa AOT, Sunmonu TO, Afolayan AJ. Toxicological evaluation of aqueous leaf and berry extracts of
Phytolacca dioica L. in male Wistar rats. Food Chem Toxicol 2010; 48: 1886-1889.

14. Ashafa AOT, Orekoya LO, Yakubu MT. Toxicity profile of ethanolic extract of Azadirachta indica stem bark in male Wistar rats. Asian Pac J Trop Biomed 2012; 2: 811-817.

15. Tietz NW. Clinical guide to laboratory tests, 3rd ed, Philadelphia: W.B. Saunders 1995

16. Krause WJ. The art of examining and interpreting histologic preparations; A student's handbook. UK: Partheton Publishing Group 2001; pp 9-10.

17. Adeneye AA, Ajagbonna OP, Adeleke TI, Bello SO. Preliminary toxicity and phytochemical studies of the stem bark aqueous extract of Musanga cecropioides in rats. J Ethnopharmacol 2006; 105: 374-379.

18. Kytridis VP, Manetas Y. Mesophyll versus epidermal anthocyanins as potential in vivo antioxidants: evidence linking the putative antioxidant role to the proximity of oxy-radical source. J Exp Bot 2006; 57: 2203-2210.

19. Latha RM, Geentha T, Varalakshmi P. Effect of Vernonia cinerea Less. flower extract in adjuvant-induced arthritis. Gen Pharmacol 1998; 31: 601-606.

20. Shahjahan M, Sabitha KE, Mallika J, Shyamala-Devi CS. Effect of Solanum trilobatum against carbon tetrachloride induced hepatic damage in albino rats. Indian J Med Res 2004; 120: 194-198.

21. Akanji MA, Yakubu MT, Kazeem MI. Hypolipidemic and toxicological potential of aqueous extract of Rauvolfia vomitoria Afzel root in wistar rats. J Medical Sci 2013; 13: $253-260$

22. Halperin ML, Goldstein MB. Fluid, electrolyte and acidbase physiology: A Problem-based approach, 2nd ed, Philadelphia: WB Saunders 1994.

23. Crook MA. Clinical Chemistry and Metabolic Medicine. 7th edn, London: Hodder Arnold 2006.

24. Moe SM, Drueke T, Lameire N, Eknoyan G. Chronic kidney disease-mineral-bone disorder: $A$ new paradigm. Adv Chronic Kidney Dis 2007; 14: 3-12.

25. Chawla R. Kidney function tests, In: Practical Clinical Biochemistry; Methods and interpretation. 2nd ed, New Delhi: Jaypee Brothers Medical Publishers (P) Ltd 1999 p. 90-92.

26. Carolla R, Harley JP, Noback CR. Regulation of body fluid electrolytes and acid base balance, In: Anatomy and Physiology, 2nd ed, New York: McGraw Hill Inc 1990.

27. Olorunnisola OS, Bradley G, Afolayan AJ. Acute and subchronic toxicity studies of methanolic extract of Tulbagia violacea rhizomes in Wistar rats. Afr J Biotech 2012; 11: 14934-14940.

28. Amresh GR, Singh PN, Rao VC. Toxicological screening of traditional medicine Laghupatha (Cissampelos pareira) in experimental animals. J Ethnopharmacol 2008; 116: 454-460.

29. Teo S, Stirling D, Thomas S, Hoberman A, Kiorpes A, Khetani V. A 90-day oral gavage toxicity study of $D$ - 
Sharaibi et al

methylphenidate and $D, \quad$ L-methylphenidate Sprague-Dawley rats. Toxicol 2002; 179: 183-196.
30. Eroschencho VP. Atlas of histology with functional correlations, 9th edn, Williams and Wilkins Lippincott, USA, 2000; $p 12$. 